\title{
Analysis of Parity Between Protein-based Electrophoretic Methods for the Characterization of Oral Candida Species
}

\author{
EAR Rosa, RT Rosa, CV Pereira, MFG Boriollo, JF Höfling ${ }^{+}$
}

\author{
Laboratório de Microbiologia e Imunologia, Faculdade de Odontologia de Piracicaba, Unicamp, \\ Av. Limeira 901, 13414-900, Piracicaba, SP, Brasil
}

Electrophoretic studies of multilocus-enzymes (MLEE) and whole-cell protein (SDS-PAGE) were carried out in order to evaluate the parity between different methods for the characterization of five Candida species commonly isolated from oral cavity of humans by numerical taxonomy methods. The obtained data revealed that sodium dodecyl sulfate polyacrylamide gel electrophoresis is more efficient in grouping strains in their respective species while MLEE has much limited resolution in organizing all strains in their respective species-specific clusters. MLEE technique must be regarded for surveys in which just one species of Candida is involved.

Key words: polyacrylamide gel electrophoresis - multilocus enzyme electrophoresis - Candida numerical analysis

The yeasts pertaining to the genus Candida are found dispersed in different epitelial areas of the body, including oral mucosa. In recent years, they have received more attention due to their involvement in a increasing number of cases of opportunist oral infections in patients with Aids and those having immunosuppresive medication. Of epidemiological interest, characterization procedures based on molecular fingerprints have been applied in order to establish possible relationships among Candida isolates involved in oral infections (McCullough et al. 1996).

Different types of electrophoretic techniques have been used for the characterization or typing of Candida including electrophoretic separation of chromosomes (Monod et al. 1990, Asakura et al. 1991), DNA fragments (Scherer \& Stevens 1987), multilocus-enzymes (Lehmann et al. 1989a, Pujol et al. 1993, Reynes et al. 1996), and whole-cell proteins (Shen et al. 1988, Vancanneyt et al. 1991, 1992, Höfling et al. 1998). The two latter methods have been used successfully for yeast characterization. The resulting electrophoretic profiles can be plotted into a binary data matrix that, with com-

\footnotetext{
This work received financial support from "Fundação de Amparo à Pesquisa do Estado de São Paulo" and "Fundo de Apoio ao Ensino e Pesquisa, Unicamp". ${ }^{+}$Corresponding author. Fax: +55-19-430.5218. E-mail: hofling@fop.unicamp.br

Received 1 October 1999

Accepted 26 June 2000
}

puter-assisted support, produces comparative results expressed as similarity or cophenetic correlation matrices or dendrograms (Kersters 1985).

In this experiment, we compare multilocus-enzyme electrophoresis (MLEE) and polyacrylamide gel electrophoresis (SDS-PAGE) for their ability to discriminate five Candida species isolated from saliva of healthy subjects.

\section{MATERIALS AND METHODS}

Candida strains - Representative strains of different Candida species isolated from human oral cavity and identified by biochemical and physiological tests were obtained from the Microbiology and Immunology Laboratory, Dentistry College of São José dos Campos: C. albicans (97.a, F.72, E.37, 17.b, CBS.562 $\left.{ }^{\mathrm{T}}\right)$, C. guilliermondii (FCF.405, FCF.152, CBS.566 ${ }^{\mathrm{T}}$ ), C. parapsilosis (21.c, 7.a,CBS. $604^{\mathrm{T}}$ ), C. krusei (1M.90, 4.c, CBS. $573^{\mathrm{T}}$ ), C. tropicalis (1.b, FCF.430, CBS.94 ${ }^{\mathrm{T}}$ ). The superscript T in CBS strains indicates that they are the respective type-strains for each species. Saccharomyces cerevisiae type-strain $\left(\mathrm{CBS} .1171^{\mathrm{T}}\right)$ was included as an extra-generic organism (Costas et al. 1989).

Cell cultivation and whole-cell protein extraction - All strains were grown in $50 \mathrm{ml}$ of Yeast Peptone Dextrose medium (2\% dextrose, $2 \%$ peptone, $1 \%$ yeast extract) in a shaker table under 150 $\mathrm{rpm}$, at $30^{\circ} \mathrm{C}$, overnight. The cells were harvested by centrifugation at $2,000 \mathrm{~g}$ for $3 \mathrm{~min}$ and the pellets were washed four times with cold sterile water in order to remove either culture medium traces or extra-cellular metabolites (Woontner \& Jaehning 1990). The last washed pellets were transferred to $2 \mathrm{ml}$ microcentrifuge tubes and acid-washed glass 
beads (v/v) plus $200 \mathrm{ml}$ of cold sterile water were added. Cells were lysed using a Mini-Bead Beater cell disrupter (Biospec) at 4600 r.p.m., repeating four times of $30 \mathrm{sec}$ at 5 -min intervals, and placed in an ice bath. After cell disruption, the micro-centrifuge tubes were centrifuged at $10,000 \mathrm{~g}$ for 2 min, and the supernatant's protein concentration were determined according to Bradford (1976) and adjusted to $80 \mu \mathrm{g} / \mathrm{ml}$ (Ames 1974). The MLEE supernatants were applied on Whatman 3 filter paper wicks of $5 \times 12 \mathrm{~mm}$ (Selander et al. 1986), and for SDS-PAGE technique equal volumes of supernatant and loading buffer of Bruneau and Guinet (1989) (5mM Tris, 2.5\% 2-mercaptoethanol, $1.5 \%$ SDS, $0.025 \%$ bromophenol blue) were combined and heated in a boiling water bath for $10 \mathrm{~min}$.

MLEE and specific-enzyme staining - The electrophoreses were carried out using hydrolyzed corn starch Penetrose 30 (Refinações de Milho Brasil) up to a final concentration of $13 \%$ (Val et al. 1981) in 1:30 pH 8.0 Tris-citrate buffer (Selander et al. 1986, Caugant \& Sandven 1993). Electrophoreses were carried out at $4^{\circ} \mathrm{C}$ and $130 \mathrm{~V}$ until the bromphenol blue migration markers had run at least $80 \mathrm{~mm}$ from application point. At this time, the electrophoresis was interrupted and the gels were sliced with $1.2 \mathrm{~mm}$ thickness. The gel slices were revealed for enzyme active band detection, according to Selander et al. (1986) protocols. Enzymatic systems assayed were: alcohol dehydrogenase (ADH-E.C. 1.1.1.1), lactate dehydrogenase (LDH -E.C. 1.1.1.27), malate dehydrogenase (MDH-E.C. 1.1.1.37), isocitrate dehydrogenase (IDH-E.C. 1.1.1.42), glucose-6-phosphate dehydrogenase (G6PDH-E.C. 1.1.1.49), aspartate dehydrogenase (ASDH-E.C. 1.4.3.x), glucose dehydrogenase (GDH-E.C. 1.1.1.47), mannitol dehydrogenase (MADH-E.C. 1.1.1.67), sorbitol dehydrogenase (SDH-E.C. 1.1.1.14), malic enzyme (ME-E.C. 1.1.1.40), aconitase (ACO-E.C. 4.2.1.3), catalase (CAT-E.C. 1.11.1.6), superoxide dismutase (SOD -E.C. 1.15.1.1), glutamate-oxalacetate transaminase (GOT-E.C. 2.6.1.1), $\alpha$-esterase (EST-E.C. 3.1.1.1), $\beta$-esterase (EST-E.C. 3.1.1.1), leucine aminopeptidase (LAP-E.C. 3.4.1.1), glucosil transferase (GTF-E.C. 2.4.1.11), peroxidase (PO-E.C. 1.11.1.7) e $\alpha$-amylase ( $\alpha$-AM-E.C. 3.2.1.1).

SDS-PAGE protein analysis - SDS-PAGE protein profiles were obtained after electrophoresis of $50 \mu$ of protein solution in polyacrylamide slab gel with sodium dodecylsulfate (SDS) in a discontinuous buffer system (Laemmli 1970) with $4.5 \%$ stacking gel and $12.5 \%$ running gel. The electrophoresis was conduced at 125 volts in a cold chamber and the gels were stained with Coomassie blue G-250 $0.25 \%$. After destaining, the gels were scanned and the profiles of each lane transferred to a densitometry interface in the SigmaGel software (Jandel software) where the exact position of the protein peaks were determined.

Computing numerical data - Dendrograms for the different MLEE systems and SDS-PAGE were generated by using the simple matching $\left(\mathrm{S}_{\mathrm{SM}}\right)$ association coefficient (Sokal \& Michener 1958, Sneath \& Sokal 1973, Naumov et al 1997), based on band positions calculated by the NTSYS software package, version 1.70 (Applied Biostatistics, Inc.). For the present study, a $S_{S M}$ of 1.00 represents identical matches (i.e., all the bands match), $\mathrm{a} \mathrm{S}_{\mathrm{SM}}$ of 0.00 represents no matches, and increasing intermediate values represent increasing proportions of matched bands. Dendrograms, represented by non-rooted trees, based on $\mathrm{S}_{\mathrm{SM}}$ values were generated by the unweighted pair-group arithmetic average (UPGMA) clustering method (Rohlf 1963, Sneath \& Sokal 1973, Naumov et al. 1997).

\section{RESULTS}

The application of UPGMA clustering produced two similarity dendrograms shown in Figs 1 and 2, in which several clusters (phenons) could be distinguished. These clusters may be defined by their average similarity values $\left(\mathrm{S}_{\mathrm{SM}}\right)$.

\section{Phenons generated by SDS-PAGE}

Phenon I: there is the $S$. cerevisiae type-strain CBS. $1171^{\mathrm{T}}$

Phenon II: there are three strains of C. krusei, with $S_{S M} \geq 0.872$.

Phenon III: there are three strains of $C$. tropicalis, with $\mathrm{S}_{\mathrm{SM}} \geq 0.897$

Phenon IV: there are three strains of $C$. guilliermondii, with $\mathrm{S}_{\mathrm{SM}} \geq 0.823$

Phenon V: there are three strains of $C$. parapsilosis, with $\mathrm{S}_{\mathrm{SM}} \geq 0.833$

Phenon VI: there are five strains of $C$. albicans, with $\mathrm{S}_{\mathrm{SM}} \geq 0.833$

Interspecific comparison by SDS-PAGE - Among all the species, $C$. albicans (phenon VI) was the most frequently isolated species and its cluster could be grouped to others with $\mathrm{S}_{\mathrm{SM}}=0.513$.

C. krusei (phenon II) showed some similarity with $S$. cerevisiae CBS 1171 with $\mathrm{S}_{\mathrm{SM}}=0.692$, and both could be isolated from others with $\mathrm{S}_{\mathrm{SM}}=$ 0.597 .

C. guilliermondii (phenon IV) and $C$. parapsilosis (cluster $\mathrm{V}$ ) showed a value of $\mathrm{S}_{\mathrm{SM}}=$ 0.7749 , and these two clusters could be grouped with C. tropicalis (phenon III) with $\mathrm{S}_{\mathrm{SM}}=0.655$.

Reproducibility of SDS-PAGE patterns - The protein profiles of analyzed strains on different gels were reproducible after three repetitions of each electrophoretic running. Protein extracts of $S$. 
cerevisiae (CBS 1171) and molecular mass markers were applied in all gels providing mean values $\mathrm{S}_{\mathrm{SM}}=0.853$ and 1.000 , respectively.

Enzymatic systems - The one-dimensional electrophoreses of protein extracts from 12 Candida strains, their respective type-strains, and $S$. cerevisiae type-strain, showed that among twenty assayed enzymes, five did not show any enzymatic activity (ASDH, MADH, SDH, GTF, and $\alpha-\mathrm{AM}$ ).

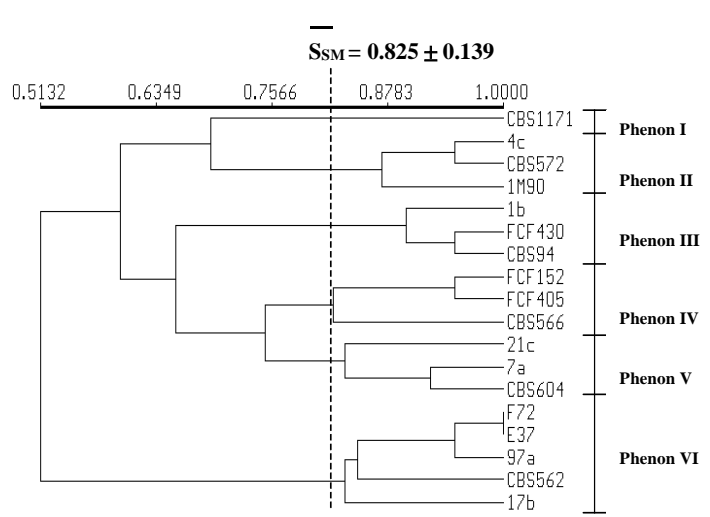

Fig.1: non-rooted dendrogram of similarity among Candida strains grouped by simple matching associative coefficient and UPGMA algorithm from sodium dodecyl sulfate polyacrylamide gel electrophoresis profiles.

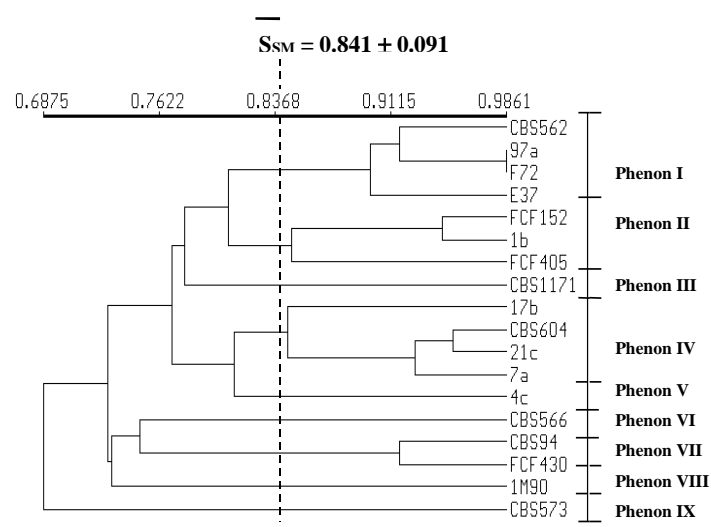

Fig. 2: non-rooted dendrogram of similarity among Candida strains grouped by simple matching associative coefficient and UPGMA algorithm from multilocus enzyme electrophoresis profiles.

\section{Phenons generated by MLEE}

Phenon I: there are four strains of $C$. albicans (CBS.152 ${ }^{\mathrm{T}}$, 97.a, F.72, and E.37) with $\mathrm{S}_{\mathrm{SM}} \geq$ 0.898

Phenon II: there are two strains of $C$. guilliermondii (FCF.152 and FCF.405) and one C. tropicalis (1.b), with $\mathrm{S}_{\mathrm{SM}} \geq 0.847$

Phenon III: there is the $S$. cerevisiae type-strain CBS. $1171^{\mathrm{T}}$
Phenon IV: there are three strains of $C$. parapsilosis (CBS.604 ${ }^{\mathrm{T}}, 21 . c$, and 7. a) and one C. albicans strain (17.b), with $\mathrm{S}_{\mathrm{SM}} \geq 0.845$

Phenon V: there is a $C$. krusei strain (4.c)

Phenon VI: there is the $C$. guilliermondii typestrain CBS. $566^{\mathrm{T}}$

Phenon VII: there are two strains of $C$. tropicalis (CBS.94T, and FCF.430), with $\mathrm{S}_{\mathrm{SM}}=0.917$

Phenon VIII: there is the strain $1 \mathrm{M} .90$ of $C$. krusei

Phenon IX: there is the $C$. krusei type-strain $\left(\mathrm{CBS} .573^{\mathrm{T}}\right)$

Interspecific comparison by MLEE - Excluding phenon I, composed only by C. albicans, and those in which only one strain were detected (phenons III, V, VI, VIII, and IX), all other clusters had an impure composition with more than one species component.

\section{DISCUSSION}

The analysis of electrophoretic profiles of proteins and multilocus-enzymes has allowed the identification, classification of numerous strains, species and genera of yeasts (Baptist \& Kurtzman 1976, Okunishi et al. 1979, Yamazaki \& Komagata 1981, Maiden \& Tanner 1991, Vancanneyt et al. 1991, 1992).

The reproducibility of electrophoretic profiles on different slab SDS-PAGE gels was evaluated by the inclusion of molecular mass markers, besides protein extract of a organism from a non-correlated genus (Costas et al. 1989, Bruneau \& Guinet 1989 ) and gave similarity correlation values $S_{S M}$ $=0.853$ for three repetitions of $S$. cerevisiae and $\mathrm{S}_{\mathrm{SM}}=1.000$ for three repetitions of molecular mass markers. These values are in agreement with the minimum acceptable proposed by Sneath and Johnson (1972) that was 0.800. The data obtained from grouping of Candida strains based on their electrophoretic profiles showed high level of agreement with the inter-specific classification established by conventional methods. Moreover, the isolates of each species showed identical or very similar profiles when compared. This fact suggests that these protein profiles obtained by SDS-PAGE are relatively stable taxonomic characteristics.

As shown in Fig. 1, the use of type-strains allowed the identification of clusters at the species level, since the Candida isolates were grouped with their respective type-strains. With regard to cluster compositions, the SDS-PAGE technique allowed the organization of all isolates in distinct clusters, with similarity coefficients $\mathrm{S}_{\mathrm{SM}} \geq 0.833$ for C. albicans, $\mathrm{S}_{\mathrm{SM}} \geq 0.833$ for C. parapsilosis, $\mathrm{S}_{\mathrm{SM}} \geq 0.823$ for C. guilliermondii, $\mathrm{S}_{\mathrm{SM}} \geq 0.897$ for $C$. tropicalis, and $S_{\mathrm{SM}} \geq 0.872$ for C. krusei. 
Shechter et al. (1972), using non-denatured acid and basic protein electrophoresis and association coefficient of Jaccard $\left(S_{\mathrm{J}}\right)$, that excludes negative matches, obtained a phenogram in which the species $C$. albicans, $C$. kruse $i$ and $C$. parapsilosis combined among them with $40 \%$ of similarity. The species $C$. guilliermondii clustered to this group with $32 \%$ and C. parapsilosis was the last one to group, with approximately $25 \%$ of similarity. This behavior, different from that found in our research, is due to the fact that non-denatured proteins migrate through the gel according to their molecular mass, structural conformation and net charge. In contrast, SDS denatured proteins migrate according to molecular mass only. As molecular mass is more conserved than net charge, electrophoretic profiles based on this criterion should, in theory, detect better taxonomic relationships (Kersters 1985).

The systematic proximity between $C$. kruse $i$ and S. cerevisiae $\left(\mathrm{S}_{\mathrm{SM}}=0.692\right)$ assessed by SDSPAGE technique was also observed by Barns et al. (1991) in their analyses based on phylogenetic analysis of $18 \mathrm{~S}$ ribosomal sub-units RNA genes. Hendricks et al. (1989) support that Candida and Saccharomyces should have a close phylogenetic relationship, detectable by $18 \mathrm{~S}$ rRNA sequence analysis.

According to Fig. 2, the MLEE technique grouped most $C$. albicans strains into a single phenon, except for 17.b strain that was shown to be the less related. These enzymes were able to group all strains of $C$. parapsilosis with strain 17.b of $C$. albicans. Such aspect of multispecific cluster generated from MLEE was already observed by Smith et al. (1990), that characterizing different species of Brettanomyces and Dekkera, obtained a phenogram in which some strains could not be grouped with high similarity values in their respective speciesspecific clusters and with interference of some strains in other clusters. Jones and Noble (1982) established electrophoretic comparisons among species of dermatophytes based on MLEE technique showing the inclusion of isolates from certain species inner taxa of other species or even of other genera. These authors pointed out that this fact may occur when only a few isolates of each species are included in the surveys. Boerlin et al. (1995) used 16 enzymatic systems for characterizing 21 genetically atypical strains of chlamydospore-forming and germ tubepositive $C$. albicans recovered from human immunodeficiency virus-positive drug users, and demonstrated that some of these strains were grouped in different clusters, showing high diversity on allelic composition.

Extensive enzyme heterogeneity among Candida or other yeast genera had already been observed by other groups of researchers that pointed out that it may occur increasing the possibility of distributing such specimens in various groups or clusters (Lehmann et al. 1989a, 1989b, Caugant \& Sandven 1993, Naumov et al. 1997). Lehmann et al. (1991) related the phenomenon of isoenzymatic patterns changing of $C$. albicans during its conservation in laboratories, what could increase the apparent polymorphism. Pujol et al. (1997) found atypical strains of $C$. albicans in Aids patients, showing diverse allelic polymorphism.

When comparing the results assessed by SDSPAGE and MLEE, it can easily be seen that the first one is more useful for grouping isolates in their respective species, maybe due to the expression of species-specific bands while the second one perhaps better explores the variability at a sub-specific level, being useful for analyses of genetic polymorphism among strains of a certain Candida species.

In order to ensure whether or not the UPGMA algorithm assesses resemblance between two OTUs in the dendrogram constructions, a product-moment correlation coefficient was computed between the elements $S_{\mathrm{JK}}$ of the original similarity matrix $\mathrm{S}$ and cophenetic values $\mathrm{C}_{\mathrm{JK}}$ of the matrix $\mathrm{C}$ derived from the dendrogram. The cophenetic correlation coefficient is a measure of the agreement between similarity values implied by the dendrogram and those of the original similarity matrix (Sokal \& Rohlf 1962). These coefficient had values $r_{\mathrm{CS}}=0.928$ for SDS-PAGE and $r_{\mathrm{CS}}=0.932$ for MLEE, that range between 0.60 and 0.95 (Sneath \& Sokal 1973) or higher than 0.90 (Sokal \& Rohlf 1970), considered acceptable, corroborating by this way, with the finds of Farris (1969), that pointed out the fact that UPGMA algorithm always maximizes $r_{\mathrm{CS}}$ values.

The protein profile analysis by SDS-PAGE improves the knowledge about the taxonomic relationships among oral yeasts. This method shows good reproducibility and allows collection of useful information for numerical analysis. This methodology brings relevant information in systematic evaluation of related species. We propose that the grouping of Candida species by MLEE patterns from the assayed enzymes is not efficient when only based on a few isolates from more than one species, regarding such resource for surveys conduced with a single species of Candida, for what, the MLEE technique had already proved to be a useful method for systematic or epidemiological purposes.

\section{REFERENCES}

Ames GFL 1974. Resolution of bacterial proteins by polyacrylamide gel electrophoresis on slabs. J Biol Chem 249: 634-644. 
Asakura K, Iwaguchi SI, Homma M 1991. Electrophoretic karyotypes of clinically isolated yeasts Candida albicans and C. glabrata. J Gen Microbiol 137: 2531-2538.

Baptist JN, Kurtzman CP 1976. Comparative enzyme patterns in Cryptococcus laurentii and its taxonomic varieties. Mycologia 68: 1195-1203.

Barns SM, Lane DJ, Sogin ML, Bibeau C, Weisburg WG 1991. Evolutionary relationships among pathogenic Candida species and relatives. J Bacteriol 173: 2250-2255.

Boerlin P, Boerlin-Petzold F, Durussel C 1995. Cluster of oral atypical Candida albicans isolates in a group of human immunodeficiency virus-positive drug users. J Clin Microbiol 33: 1129-1135.

Bruneau S, Guinet R 1989. Rapid identification of medically important yeast by electrophoretic protein patterns. FEMS Microbiol Letters 58: 329-334.

Caugant DA, Sandven P 1993. Epidemiological analysis of Candida albicans strains by multilocus enzyme electrophoresis. J Clin Microbiol 31: 215-220.

Costas M, Holmes B, Wood AC, On SLW 1989. Numerical analysis of electrophoretic patterns of Providencia rettgeri from human faeces, urine and other specimens. J Appl Bacteriol 67: 441-452.

Farris JS 1969. On the cophenetic correlation coefficient. Syst Zool 18: 279-85.

Hendricks L, Goris A, Neefs J 1989. The nucleotide sequence of the small ribosomal subunit RNA of the yeast Candida albicans and the evolutionary position of the fungi among the eukaryotes. Syst Appl Microbiol 12: 223-229.

Höfling JF, Rosa EAR, Rochelle SLA, Spolidório DMP, Moreira D 1998. Numerical analysis variations of SDS-PAGE protein patterns using different culture media for the cultivation of Candida from the oral cavity. Rev Microbiol 28: 79-84.

Jones MG, Noble WC 1982. An electrophoretic study of enzymes as a tool in the taxonomy of the dermatophytes. J Gen Microbiol 20: 1101-1107.

Kersters K 1985 . Numerical methods in the classification of bacteria by protein electrophoresis. In $\mathrm{M}$ Goodfellow, D Jones, FG Priest (eds), Computer Assisted Bacterial Systematic, Academic Press, England, p. 337.

Laemmli UK 1970. Cleavage of strutural proteins during the assembly of the head of bacteriophage T4. Nature 227: 680-685.

Lehmann PF, Hsiao CB, Salkin IF 1989a. Proteins and electrophoresis profiles of selected Candida species. J Clin Microbiol 27: 400-404.

Lehmann PF, Kemker BJ, Hsiao CB, Dev S 1989b. Isoenzyme biotypes of Candida species. J Clin Microbiol 27: 2514-2521.

Lehmann PF, Wu LC, Mackenzie DW 1991. Isoenzyme changes in Candida albicans during domestication. J Clin Microbiol 29: 2623-2625.

Maiden MFJ, Tanner A 1991. Identification of oral yeasts by polyacrylamide gel electrophoresis. Oral Microbiol Immunol 6: 187-190.

McCullough MJ, Ross BC, Reade PC 1996. Candida albicans, a review of its history, taxonomy, viru- lence attributes, and methods of strain differentiation. Int J Oral Maxillofac Surg 25: 136-144.

Monod M, Porchet F, Baudraz R, Frenk E 1990. The identification of pathogenic yeast strains by electrophoretic analysis of their chromosomes. J Med Microbiol 32: 123-129.

Naumov GI, Naumova ES, Sniegowiski PD 1997. Differentiation of European and far east Asian populations of Saccharomyces paradoxus by allozyme analysis. Int J System Bacteriol 47: 341-344.

Okunishi M, Yamada K, Komagata K 1979. Electrophoretic comparison of enzymes from basidiomycetes in different stages of development. J Gen Appl Microbiol 25: 329-334.

Pujol C, Renaud F, Mallie M, de Meeus T, Bastide JM 1997. Atypical strains of Candida albicans recovered from AIDS patients. J Med Vet Mycol 35: 115121.

Pujol C, Reynes J, Renaud F, Raymond M, Tibayrenc M, Ayala FJ, Janbon F, Mallie M, Bastide JM. 1993. The yeast Candida albicans has a clonal mode of reproduction in a population of infected human immunodeficiency virus-positive patients. Proc Natl Acad Sci USA 90: 9456-9459.

Reynes J, Pujol C, Moreau C, Mallie M, Renaud F, Janbon F, Bastide JM. 1996. Simultaneous carriage of Candida albicans strains from HIV-infected patients with oral candidiasis, multilocus enzyme electrophoresis analysis. FEMS Microbiol Letters 137: 269-273.

Rohlf FJ 1963. Classification of Aedes by numerical taxonomic methods (Diptera, Culicidae). Ann Entomol Soc Amer 56: 798-804.

Scherer S, Stevens DA 1987. Application of DNA typing methods to epidemiology and taxonomy of Candida species. J Clin Microbiol 25: 675-679.

Selander RK, Caugant DA, Ochman DA, Musser JM, Gilmour MN, Whittam TS. 1986 Methods of multilocus enzyme electrophoresis for bacterial population genetics and systematics. Appl Environ Microbiol 51: 873-884.

Shechter Y, Landau JW, Dabrowa N 1972. Comparative electrophoresis and numeral taxonomy of some Candida species. Mycologia 64: 841-853.

Shen HD, Choo KB, Tsai WC 1988. Differential identification of Candida species and other yeasts by analysis of $\left[{ }^{35} \mathrm{~S}\right]$ - metionine labeled polypeptide profiles. Analyt Biochem 175: 548-555.

Smith MT, Yamazaki M, Poot GA 1990. Dekkera, Brettanomyces and Eeniella, electrophoretic comparison of enzymes and DNA-DNA homology. Yeast 6: 299-310.

Sneath PHA, Johnson R 1972. The influence on numerical taxonomy similarities of errors in microbial testes. J Gen Microbiol 72: 248-255.

Sneath PHA, Sokal RQ 1973. Numerical Taxonomy, Freeman, San Francisco, 573 pp.

Sokal RR, Michener CD 1958. A statistical method for evaluating systematic relationships. Univ Kansas Sci Bull 38: 1409-1438.

Sokal RR, RohlfFJ 1962. The comparison of dendograms by objective methods. Taxon 11: 33-40. 
Sokal RR, Rohlf FJ 1970. The intelligent ignoramus, an experiment in numerical taxonomy. Taxon 19: 305319.

Val AL, Schwantes AR, Schwantes MLB, de Luca PH 1981. Amido hidrolisado de milho como suporte eletroforético. Ci Cult 33: 992-996.

Vancanneyt M, Lerberge EV, Berny JF, Hennebert GL, Kersters K 1992. The application of whole-cell protein electrophoresis for the classification and identification of basidiomycetous yeast species. Antonie van Leeuwenhoek 61: 69-78.
Vancanneyt M, Pot B, Hennebert G, Kersters K 1991. Differentiation of yeast species based on electrophoretic whole-cell protein patterns. Syst Appl Microbiol 14: 23-32.

Woontner M, Jaehning JA 1990. Accurate initiation by RNA polymerase II in a whole cell extract from $\mathrm{Sac}$ charomyces cerevisiae. J Biol Chem 265: 8979-8982.

Yamazaki M, Komagata K 1981. Taxonomic significance of electrophoretic comparison of enzymes in the genera Rhodotorula and Rhodosporidium. Int J Syst Bacteriol 31: 361-381. 